\title{
The distribution and habitat preferences of an extremely rare European spider, Glyphesis taoplesius (Araneae: Linyphiidae)
}

\author{
Maria Oleszczuk, Izabela Hajdamowicz \& Marzena Stańska
}

\begin{abstract}
Oleszczuk, M., Hajdamowicz, I. \& Stańska, M. 2011: The distribution and habitat preferences of an extremely rare European spider, Glyphesis taoplesius (Araneae: Linyphiidae). - Entomol. Fennica 22: 15-20.

Glyphesis taoplesius Wunderlich, 1969 is a very rare spider species that has only been found in a few locations in Europe. Two specimens of G. taoplesius were recently collected in the Bug river valley in eastern Poland. It is the first record of this species in Poland. A morphological description of the male and a distribution map of the species are given in the paper. G. taoplesius is a hygrophilous spider typically found near bodies of water and the Polish specimens were found in a periodically flooded meadow.

M. Oleszczuk, Institute for Agricultural and Forest Environment, Polish Academy of Sciences, Field Station, Szkolna 4, Turew, 64-000 Kościan, Poland; Email:oleszczukm@vp.pl

I. Hajdamowicz \& M. Stańska, Department of Zoology, University of Podlasie, B. Prusa 12,08-110 Siedlce, Poland; E-mails: hajdamo@ap.siedlce.pl \& stanska@ap.siedlce.pl
\end{abstract}

Received 12 February 2010, accepted 1 June 2010

\section{Introduction}

Four spider species of the genus Glyphesis Simon, 1926; have been found in Europe: G. taoplesius Wunderlich, 1969; G. cottonae La Touche, 1944, G. servulus Simon, 1881 and G. nemoralis Esyunin \& Efimik, 1994 (van Helsdingen 2009, Platnick 2010).

These species are characterised by their very small body size (about $1 \mathrm{~mm}$ ). Moreover, they are hygrophilous, stenotopic, and are considered to be rare or very rare spider species (Platen et al. 1999, Nentwig et al. 2003, Staudt 2010). G. servulus, the smallest species of the genus, is recorded more often than the other three species and has been reported altogether in 14 European countries (van Helsdingen 2009, Blick et al.
2004, Staudt 2010). Nevertheless, in Germany and Slovakia it still belongs to the group of endangered species (Gajdoš et al. 1999, Platen et al. 1996, 1998), and in Czech Republic and Poland is regarded as a vulnerable species (Buchar \& Růžička 2002, Staręga et al. 2002). G. cottonae has been reported in fewer European countries (8 countries) than $G$. servulus (van Helsdingen 2009). In Germany it is classified as critically endangered and in Poland as an endangered species (Platen et al. 1996, 1998, Staręa et al. 2002). Glyphesis taoplesius is a very rare species that has only been found in four countries in Europe: Denmark (Scharff \& Gudik-Sørensen 2006), Germany (Staudt 2010), Hungary (Szinétar 1995) and Russia (Esyunin et al. 1998, Mikhailov 1999) (Fig. 1). This species was initially de- 


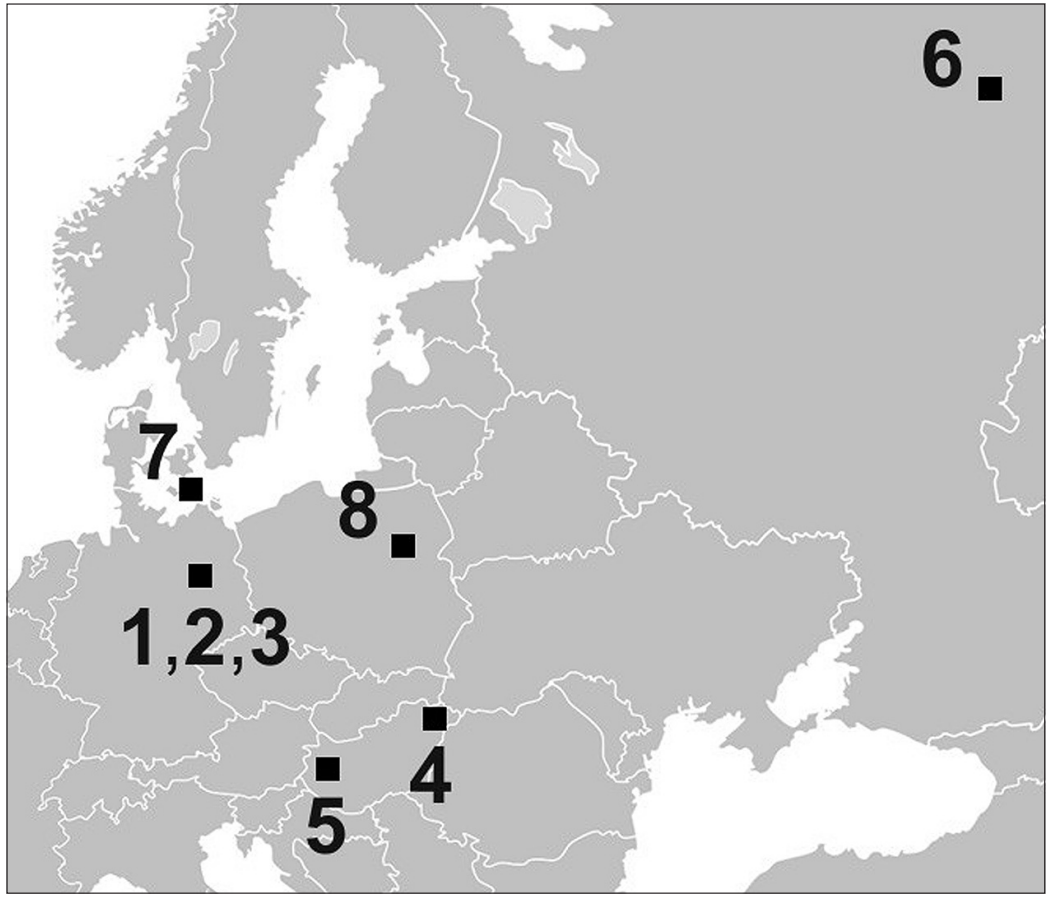

Fig. 1. Known records of Glyphesis taoplesius. Stands are indicated as black squares. The locations are: Germany: 1 - Berlin (locus typicus), 2 - Potsdam, 3 - Wilhelmshorst; Hungary: 4 - Csaroda, 5 Balatongyörök; Russia: 6-Kishert; Denmark: 7 - Ulvshale; Poland (new record): 8 - Morzyczyn. scribed from Germany by Wunderlich (1969). It is reported as a critically endangered species on the Red Data List of this country (Platen et al. 1996, 1998). In the Danish Red List (2004) it has the DD status (Data Deficient). G. nemoralis has only been recorded in Eastern Europe - Russia (Urals) and Ukraine (Esyunin et al. 1998, Mikhailov 1999).

This paper presents a new record of Glyphesis taoplesius in eastern Poland as well as the distribution and habitat preferences of this extremely rare spider.

\section{Material and methods}

The specimens of $G$. taoplesius were obtained during a research project: "Habitat heterogeneity and diversity of selected groups of arthropods in the Bug River Valley", conducted in the years 2007 and 2008. Several representative habitats in the river valley were studied: riparian forests, rushes at oxbows, meadows of lower and upper flooded terraces, sandy grasslands, thermophilous grasslands and thermophilous brushwood. Specimens were collected using sweep nets and pitfall traps. In the first year of the study more than 50,000 spiders were caught, but G. taoplesius was not observed in any of the habitats.

Two specimens of G. taoplesius were collected in a flooded meadow near the village Morzyczyn on the Mazovian Lowland in 2008. This site was located in the Bug River Valley Landscape Park, in the area of Natura 2000. Ten pitfall traps were placed in one straight line, at a distance of 2 meters one from another. The beginning of the trapping period was in the middle of March and the end was in the middle of November.

The coordinates and height above sea level of a beginning and an end of the trap line are as follows: N52 ${ }^{\circ} 41.305^{\prime} \mathrm{E} 21^{\circ} 54.970^{\prime}, 94 \mathrm{~m}$ a.s.1. and $\mathrm{N} 52^{\circ} 41.311^{\prime} \mathrm{E} 21^{\circ}$ 54.983', 93 m a.s.1.

The collection dates were as follows: Male-1 09.05.-23.05.2008, leg. P. Jastrzębski det. M. Oleszczuk; Male-2 -21.06.-07.07.2008, leg. M. Stańska, det. M. Oleszczuk

\subsection{Habitat characteristics}

The meadow was located in the meadows and grasslands complex of lower flooded terrace 
which was underwater during high tides of the river. Based on syntaxonomy, this plant community was classified as an alluvial meadow of river valleys of the Cnidion dubii, but it demonstrated characteristics intermediate between alluvial meadows Cnidion dubii and fresh meadows (Załuski 1995, Matuszkiewicz 2005). Predominant plants were species typical of a grassy habitat: Carex praecox, Poa angustifolia and Agrostis capillaris. The dense cover also included dicotyledonous plants such as Lotus corniculatus, Ranunculus sardous and Plantago lanceolata.

The meadow was extensively subjected to human impacts and was mown once in two years. Moreover, it was periodically poorly grazed by cattle. In the complex of meadows and grasslands on the distance about $2 \mathrm{~km}$ along the river the dairy herd of approximately 20 individuals were pastured in summer.

\section{Diagnostic features}

G. taoplesius is quite easy to distinguish from other species from this genus occurring in Europe. The carapace shape of the male G. taoplesius differs from remaining species, which is best noticeable in the side view profile (Esyunin \& Efimik 1994, Nentwig et al. 2003). The carapace is slightly raised and shaped into a sharp point, with clypeus projecting a little beneath the eye region (Fig. 2). Post-ocular sulci are present, but poorly distinct in comparison with $G$. cottonae (Roberts 1993, Wunderlich 1969). The carapace has a yellow-brown colour while the median flecks, radial stripes and border are darker. The abdomen is dark grey or dark brown in colour. The legs have yellow-brown colouration. A bit similar colours are noticed in G. nemoralis, but carapace and legs of this species are yellowgray (Esyunin \& Efimik 1994). G. servulus and $G$. cottonae usually are darker - prosoma is brown or brown-black and abdomen is black in both species (Nentwig et al. 2003).

The male palp of G. taoplesius is easily distinguished from other Glyphesis-species by the shape of tibia. In G. cottonae and G. nemoralis tibial apophyses are curved and they lack the long bristles (Esyunin \& Efimik 1994, Nentwig et al. 2003). The dorsal tibial apophysis in G. servulus
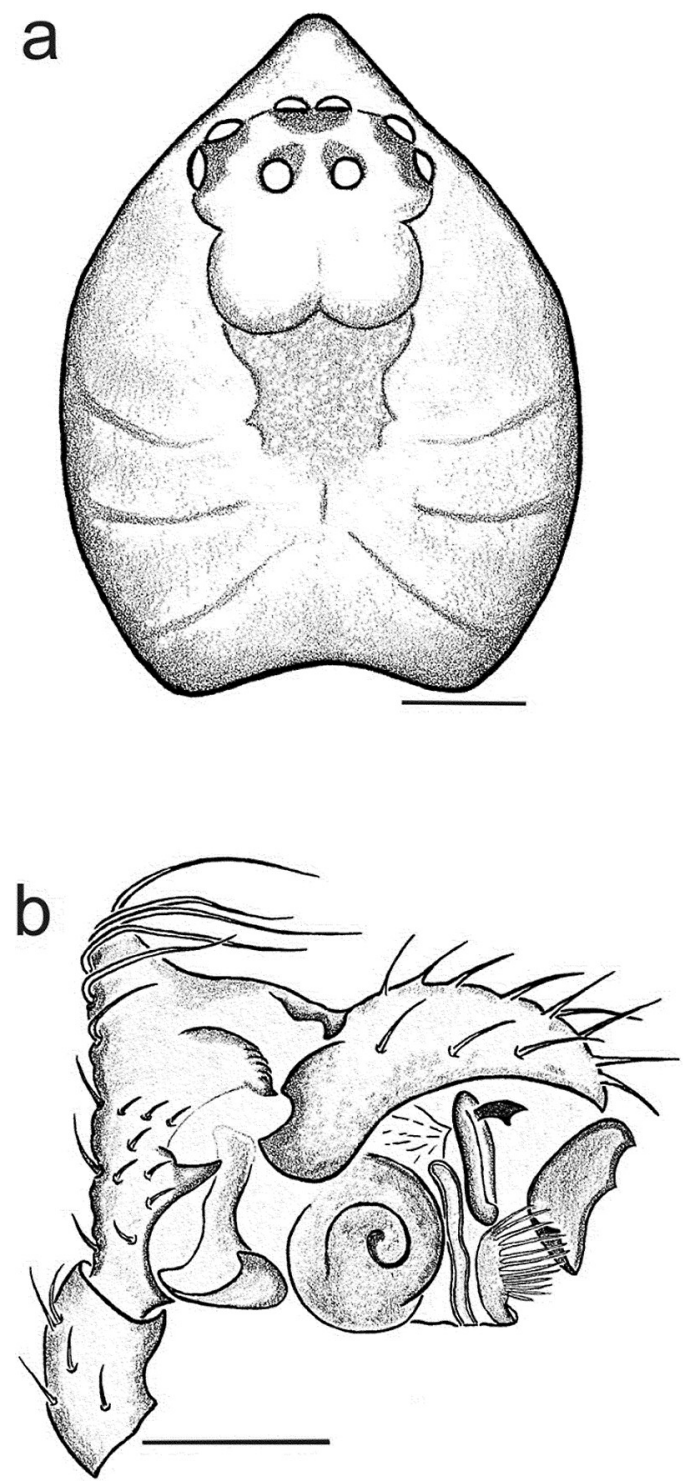

Fig. 2. Diagnostic drawings of a male of Glyphesis taoplesius. - a. Carapace, - b. Lateral view of palpal organ. Scale bar $-0,1 \mathrm{~mm}$.

is flat, almost twice longer than high and has five long bristles running along its length and continuing across the cymbium (Wunderlich 1969, Roberts 1993, Nentwig et al. 2003). By contrast, in $G$. taoplesius the dorsal tibial apophysis is highly elevated (almost as long as high) and has six long curved bristles at the top of a hump (Fig. 2).

According to the literature, G. taoplesius is very small in size with a total body length of 1.3 mm for males and females (Nentwig et al. 2003). 
Measurements of the specimens collected in Poland were as follows:

Male-1: total body length: $1.2 \mathrm{~mm}$, carapace length: $0.6 \mathrm{~mm}$, carapace width: $0.3 \mathrm{~mm}$, carapace height: $0.2 \mathrm{~mm}$, abdomen length: $0.6 \mathrm{~mm}$, abdomen width: $0.4 \mathrm{~mm}$.

Male-2: total body length: $1.2 \mathrm{~mm}$, carapace length: $0.6 \mathrm{~mm}$, carapace width: $0.4 \mathrm{~mm}$, carapace height: $0.2 \mathrm{~mm}$, abdomen length: $0.6 \mathrm{~mm}$, abdomen width: $0.3 \mathrm{~mm}$.

\section{Distribution}

Glyphesis taoplesius is an extremely rare European spider species known only from few locations. This species has only been observed in widely separated stands in Europe that include locations in Denmark (Scharff \& Gudik-Sørensen 2006), north eastern Germany (Wunderlich 1969, Moritz 1973, Platen et al. 1999), Hungary (Loksa 1981, Szinetár 1995) and the Urals in Russia (Esyunin et al. 1998) (Fig. 1). In Germany G. taoplesius was reported from four stands in the north eastern part of the country. The specimens originally described by Wunderlich (1969) were found in the outskirts of Berlin in the Pfauen Island Reserve on the Havel river. A second study conducted many years later (1983-1988) on this island did not reveal the presence of the species (Platen \& Wunderlich 1990), so the authors reported it to the Red Data List of Berlin as extinct (Platen et al. 1991). However, Blick \& Szinetár (1996) reported a new finding of this species in the reserve in 1993. The next specimen was found in neighbouring Potsdam (Brandenburg) also at the Havel River (Moritz 1973). Many years later $G$. taoplesius was recorded in Wilhelmshorst near Potsdam (Platen et al. 1999). The authors consider G. taoplesius in Brandenburg as a very rare species (1-5 locations in the region) and endangered by extinction. The presence of this species in Mecklemburg-Vorpommern has not been confirmed (Blick \& Szinetár 1996).

In Hungary the species was described by Loksa (1981) as G. conicus. However, Blick \& Szinetár (1996) reported this name as a junior synonym of $G$. taoplesius. This spider was found in stands in the northeastern part of the Hungarian
Plain near Nyírestó, in the Upper Tisza region, in a strictly protected peat bog (Loksa 1981). This species was also observed in the northwestern region of Lake Balaton, in the vicinity of Balatongyörök (Szinetár 1995).

In Denmark G. taoplesius was found in Ulvshale on Moen island in the Baltic Sea (Scharff \& Gudik-Sørensen 2006). The species is in the Danish Red List (2004) with the DD status.

G. taoplesius was also reported from Russia, in the middle Urals. One male of this species (in original text erroneously - one female) was found on the bank of the Silva River in Perm Araea, Kishert District, Preduralie Reserve, and was reported as a new record for Russia (Esyunin et al. 1998, Esyunin pers. comm.).

The first reported occurrence of this spider species in Poland comes from the northeastern part of country, on the Mazovian Lowland, in the Bug River valley at the river (present paper).

\section{Habitat and phenology}

All specimens of Glyphesis taoplesius were discovered in regions characterised by bodies of water such as large rivers, lakes, and the sea. These regions have a humid microclimate and specific conditions which create desirable habitats along the edge of water that are preferred by this species.

Habitats of G. taoplesius were correlated with the presence of large bodies of water. In Germany this species was found near a river characterised by the presence of specific vegetation including rushes Glycerietum maximae and riparian forest Pruno-Fraxinetum (Wunderlich 1969). These spiders have also been found in a thick layer of vegetation debris borne by the river (Moritz 1973). In Russia the specimens were found on the bank of a river in a Salix bed (Esyunin et al. 1998) and in Poland in a flooded meadow of the lower river terrace (present paper). This spider was captured in Hungary among reeds at a lake in an offshore bar of vegetation debris created by waves (Szinétar 1995).

Another biotope of. G. taoplesius were plant associations of wet areas characterised, at least periodically, by the presence of stagnant water. These sites were peat bogs Eriophoro vaginato- 
Sphagnetum and Carici lasiocarpae-Sphagnetum in Hungary (Loksa 1981), on the edge of a water reservoir in a eutrophic peat bog in Brandenburg Land, Germany (Platen et al. 1999), as well as an alder swamp forest DryopteridiAlnetum in Hungary (Loksa 1981) and a swamp forest in Denmark (Scharff \& Gudik-Sørensen 2006).

This species is considered to be stenotopic, and a photobiont - hygrobiont in terms of its specific habitat preferences (Platen et al. 1999). Because of the presence of $G$. taoplesius in bright forests it can be considered as a photophilous species.

Based on current data from the northern part of its range (Denmark, Germany, Poland and Russia) G. taoplesius occurred in eutrophic habitats such as riparian and alder swamp forests, willow beds, and rushes (Platen et al. 1999), while in the southern part of its range, such as Hungary, this species also occurs in oligotrophic and mesotrophic habitats like peat bogs. It is possible that in the southern part of its range the species can tolerate a broader range of habitat conditions and characteristics. However, the oligotrophic peat bog microclimate is characterised by lower temperatures than mesotrophic wetlands (Szafer \& Zarzycki 1977); therefore, northern European peat bogs might have a microclimate that is too cold for G. taoplesius.

Peak activity of $G$. taoplesius occurs in May and June (Wunderlich 1969), but this species has been collected from $5^{\text {th }}$ April (Scharff \& GudikSørensen 2006) to $8^{\text {th }}$ August (Szinetár 1995) and in present study in July. Typically this spider has been captured as a single specimen in pitfall traps (Szinetár 1995, Esyunin et al. 1998, present paper). However, Wunderlich (1969) collected 11 males and 2 females using pitfall traps in a longterm seasonal study. Loksa (1981), using the same method during a one-year study, found about 25 specimens in three peat bogs and 20 specimens in three alder swamp forests in Hungary. In a few studies, the method of capture for this species has not been disclosed (Moritz 1973, Platen et al. 1999).

One reason for the rarity of Glyphesis taoplesius is that it prefers wet habitats and the availability of such appropriate habitats has decreased dramatically over the last century in Europe
(Szafer \& Zarzycki 1977, Succow \& Jeschke 1990). In addition, there can be methodological problems of collecting spider species such as $G$. taoplesius, which prefers habitats that are particularly difficult to access. Scharff \& GudikSørensen (2006) suggested also that its small size often causes this species to be overlooked. However, smaller $G$. servulus living in the middle humid deciduous forests have been recorded often. Further investigation of wetland areas may reveal new populations of G. taoplesius throughout Europe.

Acknowledgements. The research was financed by the Polish Ministry of Science and Higher Education. We would like to thank colleagues from the Department of Zoology, especially Dr. Piotr Jastrzębski, and students of the University of Podlasie and to other persons for their help in collecting specimens, as well as Dr. Theo Blick for many valuable suggestions for the paper and Dr. Janet Lensing (Kentucky, USA) for revising the text of the manuscript.

\section{References}

Blick, T. \& Szinetár, C. 1996: Glyphesis conicus ist ein jüngeres Synonym von Glyphesis taoplesius (Araneae: Linyphiidae). — Arachnologische Mitteilungen 11: 39-42.

Blick, T., Bosmans, R., Buchar, J., Gajdoš, P., Hänggi, A., van Helsdingen, P., Růžička, V., Staręga, W. \& Thaler, K. 2004: Checkliste der Spinnen Mitteleuropas Checklist of the spiders of Central Europe (Arachnida: Araneae). Version 1. Dezember 2004. - [www document] URL http://arages.de/checklist/checklist04 _araneae.html. (Site visited on 07 April 2010).

Buchar, J. \& Růžička, V. 2002: The catalogue of spiders of the Czech Republic. — Peres Publishers, Praha. 351 pp.

Danish Red List 2004: Threatened plants and animal species: Revised Danish Red List. Danish Environment Newsletter: 30. - [www document] URL http:// www.dmu.dk/1_Om_DMU/2_Tvaer-funk/3 fdc bio/projekter/redlist/redlist_en.asp. (Site visited on 28.03.2010).

Esyunin, S. L. \& Efimik, V. E. 1994: Glyphesis nemoralis sp. n. (Aranei, Linyphiidae) from nemoral forests of the east European plain and the Urals. - Zoologič3eskij žurnal 73: 157-159. [In Russian with English summary.]

Esyunin, S. L., Efimik, V. E. \& Mazura, N. S. 1998: Remarks on the Ural spider fauna, 10 . New records of spider species (Aranei). - Arthropoda Selecta 7: 319-327.

Gajdoš, P., Svatoň, J. \& Svoboda, K. 1999: Catalogue of Slovakian spiders. — Ustav krajinnej ekológie Slo- 
venskej akademie vied, Bratislava. 337 pp.

Loksa, I. 1981: Die Bodenspinnen zweier Torfmoore im Oberen Theiss-Gebiet Ungarns. - Opuscula Zoologica, Budapest 17/18: 91-106.

Matuszkiewicz, W. 2005: Przewodnik do oznaczania zbiorowisk roślinnych Polski (A guide to identifying plant communities). - PWN, Warszawa. 540 pp. [In Polish.]

Mikhailov, K. G. 1999: Catalogue of the spiders of the of the territories of the former Soviet Union (Arachnida, Aranei). Addendum 2. - Zoological Museum of the Moscow State University, Moscow. 40 pp.

Moritz, M. 1973: Neue und seltene Spinnen (Araneae) und Weberknechte (Opiliones) aus der DDR. - Deutsche Entomologische Zeitschrift N.F. 20: 173-210.

Nentwig, W., Hänggi, A., Kropf, C. \& Blick, T. 2003: Central European spiders - determination key. Version 8.12.2003. - [www document]. URL http:// www.araneae.unibe.ch. (Site visited on 01 December 2009).

Platen, R. \& Wunderlich, J. 1990: Die Spinnenfauna des Naturschutzgebietes Pfaueninsel in Berlin. - Zoologische Beiträge N.F. 33: 125-160.

Platen, R., Moritz, M. \& Broen, B. von 1991: Liste der Webspinnen- und Weberknechtarten (Arach.: Araneida, Opilionida) des Berliner Raumes und ihre Auswertung für Naturschutzzwecke (Rote Liste). - In: Auhagen, A., Platen, R. \& Sukopp, H. (eds.), Rote Listen der gefährdeten Pflanzen und Tiere in Berlin. Landschaftsentw. Umweltforsch. S6: 169-205.

Platen, R., Blick, T., Sacher P. \&. Malten A. 1996: Rote Liste der Webspinnen Deutschlands (Arachnida: Araneae). - Arachnologische Mitteilungen 11: 5-31.

Platen, R., Blick, T., Sacher P. \& Malten, A. 1998: Rote Liste der Webspinnen (Arachnida: Araneae) (Bearbeitungsstand: 1996, 2. Fassung). - Schriftenreihe für Landschaftspflege und Naturschutz 55: 268-275.

Platen, R., Broen, B. von, Herrmann, A., Ratschker, U. M. \& Sacher, P. 1999: Gesamtartenliste und Rote Liste der Webspinnen, Weberknechte und Pseudoskorpione des Landes Brandenburg (Arachnida: Araneae, Opiliones, Pseudoscorpiones) mit Angaben zur Häufigkeit und Ökologie. - Naturschutz und Landschaftspflege in Brandenburg 8 (2), Beilage: 1-79.
Platnick N. I. 2010: The world spider catalog, version 10.5. - American Museum of Natural History, New York. [www document] URL http://research.amnh.org/ entomology/spiders/catalog/. (Site visited on 07.06. 2010).

Roberts, M. J. 1993: The spiders of Great Britain and Ireland. Compact Edition, Vols 1-2 \& Appendix to vols. 1-2. — Colchester, Harley Books. 229 pp. \& 204 pp. $\& 16 \mathrm{pp}$.

Scharff, N. \& Gudik-Sørensen, O. 2006: Catalogue of the spiders of Denmark (Araneae). — Entomologiske Meddelelser 74: 3-71.

Staręga, W., Błaszak, C. \& Rafalski, J. 2002: Araneae Pająki. — In: Głowaciński Z. (ed.), Czerwona lista zwierząt ginących i zagrożonych w Polsce. Red list of endangered animals in Poland: 133-140. Instytut Ochrony Przyrody PAN, Kraków. 155 pp.

Staudt, A. 2010: Nachweiskarten der Spinnentiere Deutschlands (Arachnida: Araneae, Opiliones, Pseudoscorpiones). - [www document]. URL http:// spiderling.de/arages/Verbreitungskarten/species. php?name=glytao. (Site visited on 07 April 2010).

Succow, M., \& Jeschke, L. 1990: Moore in der Landschaft. - Urania, Leipzig, Jena, Berlin. 268 pp.

Szafer, W. \& Zarzycki, K. (eds.). 1977: Szata roślinna Polski (The flora of Poland). - PWN, Warszawa. $615 \mathrm{pp}$. [In Polish.]

Szinetár, C. 1995: Some data on the spider fauna of reeds in Hungary. I. Interesting faunistic data from the reeds of Lake Balaton. - Folia Entomologica Hungarica 56: 205-209.

Wunderlich, J. 1969: Zur Spinnenfauna Deutschlands, IX. Beschreibung seltener oder bisher unbekannter Arten (Arachnida: Araneae). — Senckenbergiana Biologica 50: 381-393.

Van Helsdingen, P. 2009: Araneae, Linyphiidae. Fauna Europea version 2.1. - [www document]. URL http://www.faunaeur.org. (Site visited on 24 March 2010).

Załuski, T. 1995: Meadow communities of Cnidion dubii Bal. Tul 1966 alliance in Poland. - Monographiae Botanicae 77: 1-142. [In Polish with English summary.] 